\title{
To Reduce Inflation: New Application of Old Theories
}

\author{
Diana Viljoen \\ School of Economic Sciences, North-West University, Vanderbijpark, South Africa \\ Email:Diana.Viljoen@nwu.ac.za \\ André Mellet \\ School of Economic Sciences, North-West University, Vanderbilipark, South Africa \\ Email:Andre.Mellet@nwu.ac.za
}

\section{Doi:10.5901/mjss.2014.v5n21p313}

\begin{abstract}
The international financial crisis of 2008 had a major impact on capital flows from developed countries to BRICS countries. This study explores the reasons and impact of capital and exchange rate volatility that BRICS countries experienced. The rethinking of inflation theory to address the capital volatility which emerging economies face is of utmost importance. International investors invest in South Africa and other BRICS countries and are of an exogenous nature. The solution to reduce the negative impact of capital and exchange rate volatility lies with a different inflation management in each BRICS country and a reduced interest rate spectrum. The root causes of the capital volatility were investigated and not the symptomatic mechanisms to reduce the impact. This research focused on the South African inflation scenario. A new inflation index is proposed for South Africa to reduce the negative impact of capital volatility in the South African economy. The new index which excludes all exogenous factors will allow National Treasury to introduce a much lower inflation target for the monetary authority to manage. The interest rate differential of South Africa will narrow significantly relative to developed economies. The reduced interest spectrum will also bring other advantages, for example to stimulate real growth, to increase employment opportunities and to contribute towards a reduction in poverty.
\end{abstract}

Keywords: Monetary policy, international capital flows, exchange rate volatility, inflation differentials, BRICS

\section{Introduction}

The primary goals of monetary policy are to create stability in the financial markets and to foster an environment where the economy can facilitate growth and development. In the aftermath of the 2008/2009 Global Financial Crisis, monetary policy has experienced evermore limitations in applying existing instruments to achieve financial stability. As a result, destabilising imbalances continue to exist in the global economy today.

The Global Financial Crisis proved not to be a normal cyclical downturn. The crisis has highlighted the need to go beyond micro-approaches to financial regulation, supervision and traditional policy application. Capital flows to emerging markets displayed dramatic shifts over the crisis period, collapsing at the start of the crisis and rebounding during 2009 (Mohan, 2009). During 2011, the European debt crisis caused international investors to adjust their risk. Emerging countries experienced large capital outflows due to these adjustments. These fluctuations in capital flows should be controlled in order to ensure financial stability in emerging markets.

However, traditional measures of monetary policy cannot assist in this as the global economy has been tasked with ensuring that growth is facilitated in the wake of the crisis. This means that monetary policy should be relaxed, which is contrary to the need for controlled capital outflows. Clearly a new policy mix is required in order to reduce capital surges to the BRICS nations, which will also reduce negative turnaround experienced after the $3^{\text {rd }}$ quarter of 2008.

All of the Brazil, Russia, India, China and South Africa (BRICS) country grouping currencies, except China, experienced depreciation at the onset of the crisis. After this initial depreciation, the currencies of Brazil, Russia, India and South Africa experienced an appreciation toward the end of 2011 and the first half of 2012, with an accompanying depreciation in the last half of 2012. The currencies of Brazil and India have depreciated since 2013. This currency volatility questions the ability of policy makers to achieve stabilisation objectives using traditional monetary policy. Growing inflationary pressures in emerging countries heightens the need for sound economic policies. With inflation increasing in the BRICS countries, a new perspective is needed in order to reduce inflation in South Africa. If the inflation 
rate declines because of a new application of, or approach to monetary policy, interest rates should decline accordingly and the interest gap between BRICS nations and developed countries should decline. This reduced interest rate gap should reduce international capital volatility and the negative impact of a volatile exchange rate on economic growth and financial stability.

The International Monetary Fund (IMF) stated that improved multilateral surveillance is necessary in order to reduce the impact of negative spillovers. These negative spillovers include the policy actions made by one country that affects countries in other parts of the world. The IMF has identified three activities that must take place in order to reduce these spillovers, namely, reviewing economic theory to address the global crisis, reviewing economic policy and its implementation, and the improvement of multilateralism and global cooperation efforts amongst countries (Strauss-Kahn, 2011).

In this article, the need to rethink traditional economic theory and policy advice in the wake of the global crisis is debated. Against the background of the statement made by the IMF, this article contains an analysis of inflation differentials amongst emerging countries (BRICS countries in particular) and probable policy changes to reduce negative spillovers for emerging economies.

Policies available for emerging countries will be discussed with additional reference to macroprudential policies available to financial authorities. Determinants that influence exchange rates will be described and Keynesian views on exchange rates will be discussed. The symptoms and causes of international capital flows will be discussed by means of a comparison of interest rates and inflation differentials amongst the United States of America (USA), Europe, Japan and the BRICS countries. The solution to reduce international capital volatility is addressed.

\section{Policies Available to Emerging Economies}

According to Santomero (2001), monetary policy authorities should provide price stability in the markets and create an environment that fosters sustainable growth. Underpinning the philosophy of monetary policy is the traditional economic principles of price stability and its contribution toward economic growth and development. Price stability is crucial in order for an economy to function. Should prices fluctuate in response to supply and demand change and this is combined with excess money supply and sustained credit, inflation would increase.

Monetary authorities are, however, limited in their capacity to assess and influence these price fluctuations and, by extension, measure economic performance (Santomero, 2001). Questions such as how close the economy is to full potential or how robust demand should be in order to impact negatively on inflation, must be asked. If good readings of economic parameters are difficult to achieve, the effect of individual saving and investment decisions based on stock market wealth changes, perceived opportunities and a possible change of fiscal policy can be added.

A second limitation is the lack of capacity to model people's economic behaviour. Market participants are emotional beings that over- or underreact to changes that result in market optimism and pessimism. The decisions and expectations of market participants are, therefore, not always rational. The third limitation is that monetary authorities try to stabilise the economy with a blunt instrument, namely, the repurchase (repo) rate. The repo rate is subject to long and variable time lags. In summary, monetary authorities have limited capacity to measure economic performance precisely in real time which limits their stabilization policy ability in the short run.

To add to the above mentioned limitations (Stern et al., 2004) states that monetary authorities can give too much emphasis to short term output stabilisation rather than long term price stabilisation. Empirical findings proved that output responds temporarily in the short term. Empirical findings also proved that prices change permanently over the medium to long term and sustained increases in inflation reduce output over the long term.

Monetary policy should be analysed according to certain principles (Mishkin, 2010). The first eight principles are known as the new neoclassical synthesis. The last principle has been added since the financial crisis. The following scientific principles should be used to examine monetary policy which is derived from theory and empirical research:

- Inflation is a monetary phenomenon;

- Price stability has important benefits;

- No long-run trade off exist between unemployment and inflation;

- Expectations play an important role in the determination of inflation and transmission of monetary policy to the macro economy;

- The Taylor principle is applicable, namely that real interest rates need to rise when inflation rises;

- Monetary policy experiences a time inconsistency problem;

- Central bank independence improves an efficient monetary policy; 
- A strong nominal anchor is necessary; and

- Financial frictions play an important role in business cycles.

The application of available policies for emerging economies in a financial crisis is twofold. A distinction is necessary between an outflow of capital and an inflow of capital. The outflow of capital during the latter half of 2008 will be addressed first. The spectrum of options for emerging market economies is limited (Ghosh et al., 2009). The first response is to allow the exchange rate to depreciate. This will help these economies to cope with weaker international demand, but it may cause adverse balance of payments effects and also initiate inflation. The second response is to increase interest rates and simultaneously tighten credit conditions. This may restore confidence in the value of the currency, but during an international crisis foreign investors flee the country, want to reduce risk and move their capital to safe heavens. The third response for emerging economies is to borrow from the IMF. Monetary authorities can borrow from various funds at the IMF to ease the constraint on their reserves. The last response is to impose capital controls on the outflow of capital. This will create a wrong perception which will reduce potential inflow of new capital.

The inflow of capital since 2009 when confidence was restored towards emerging economies will be addressed secondly. The developed economies responded to the crisis through monetary and fiscal policy easing on an unprecedented scale. The interest differential between these developed economies and emerging economies widened. These countries' authorities had little scope to implement an accommodative monetary policy stance because the policies had to restore confidence first. In countries where there was scope for a more accommodative monetary policy, monetary authorities had to be mindful of the trade-off between a decreased interest rate spectrum and the negative effect of a depreciating currency on balance sheets that are not hedged.

According to Ghosh et al. (2009), monetary authorities in emerging economies have several instruments to address capital inflows at their disposal. Firstly, interest rates can be lowered as part of an accommodative monetary policy stance. This policy stance has however limitations because country specific circumstances did not allow the same scale of stimulatory stance as in developed countries. Secondly, quantitative measures can be employed. This is a policy option if credit markets remain unresponsive to a stimulatory stance or when monetary authorities have to intervene if a systemic bank crisis develops. Thirdly, monetary authorities may intervene in the foreign exchange market to stabilize the exchange rate. This policy stance also has limitations because the scope of reserves required to intervene in the foreign exchange markets is limited. Lastly, central banks may drain liquidity in the local financial market and increase the national reserves.

In addition to these measures, policy makers may adjust the monetary versus fiscal policy mix to tighten the fiscal policy stance whilst allowing interest rates to decrease (Zhu, 2011). This policy stance has its limitations because most emerging countries' scope to reduce interest rates is limited because of higher inflation rates than in developed economies. Lastly, capital control measures or macro prudential measures may be imposed. These measures will be referred to in the next section.

If all these measures are analysed, policy measures must be aligned to country-specific circumstances. The spillover effects of these different policy measures may be different from country to country. The applied policy measures can only influence the effect of these capital surges, which are mainly driven by exogenous factors in developed countries whose economies are far bigger than most emerging economies.

\section{Macroprudential Policies}

Before the available instruments of macro prudential policies are referred to, it is necessary to firstly define what systemic risk is all about. According to Hoogduin (2010), systemic risk is the risk of disruption to financial services. This disruption weakens the financial system which can cause negative consequences for the real economy. Monetary policy adjustments by means of interest rate changes and the application of macroprudential instruments should act as dual reinforcements and, in turn, influence or adjust financial conditions in the markets.

Two viewpoints are described under macroprudential policy (Galati \& Moessner, 2011). The first viewpoint is that financial stability is influenced by external shocks. The second viewpoint indicates that financial instability can be influenced by endogenous shocks that originate from within the financial market. According to these two views, the goal of macroprudential policy is to limit the risks and costs of a systemic crisis. In Table 1, the goals and instruments of macroprudential policy are compared with other policies available to policymakers. 
Table 1: Alternative sets of tools to foster financial stability

\begin{tabular}{|l|l|l|}
\hline Tool set & Goal & Instruments \\
\hline Prudential policy: Micro & Limit distress of individual institutions & e.g. quality/quantity of capital, leverage ratio \\
\hline Prudential policy: Macro & Limit financial system-wide distress & e.g. countercyclical capital charges \\
\hline \multirow{3}{*}{ Monetary policy } & Price stability & Policy rate, standard repos \\
\cline { 2 - 3 } & Liquidity management & Collateral policies; interest on reserves; policy corridors \\
\cline { 2 - 3 } & Lean against financial imbalances & $\begin{array}{l}\text { Policy rate; reserve requirements; mop-up of liquidity; FX } \\
\text { reserve buffers }\end{array}$ \\
\hline Cascal policy & Manage aggregate demand & $\begin{array}{l}\text { Taxes; automatic stabilizers; discretionary countercyclical } \\
\text { measures }\end{array}$ \\
\cline { 2 - 3 } & Build fiscal buffers in good times & $\begin{array}{l}\text { e.g. measures to reduce debt levels; taxes/levies on the } \\
\text { financial system }\end{array}$ \\
\hline Infrastructure policies & Limit system-wide currency mismatches & $\begin{array}{l}\text { e.g. limits on open foreign exchange positions; constraints on } \\
\text { the type of foreign currency assets }\end{array}$ \\
\hline infrastructure of the financial system & e.g. move derivative trading on exchanges \\
\hline
\end{tabular}

Source: Galati \& Moessner (2011)

Macroprudential policies are being used more frequently by policymakers. Some emerging countries use these instruments to target mortgage lending and to tighten capital requirements against household credit (Caruana, 2011). According to Mishkin (2010), macroprudential policies have another impact, that is, to dampen the interaction between credit provision and asset price bubbles. A rise in asset values normally results in increased capital buffers at financial institutions which supports increased lending if capital adequacy stays unchanged for mortgage loans. Bank capital requirements are important in all phases of the economy cycle. Macroprudential instruments should however, not be confused with administrative capital controls.

According to Hoogduin (2010) macroprudential policy should strengthen a financial system's resilience against shocks, as well as reduce the effect of financial shocks. Macroprudential policy should, however, compliment other policies in order to negate the impact of potential financial shocks. Table 2 provides a brief summary of the risk measurement methodologies that can be followed under macroprudential policies.

Financial instability contains systemic risks. Macroprudential policy is not concerned with the management of risk of individual financial institutions, but rather concerned with the reduction of risks in the financial markets that can eventually influence the macro environment negatively. Macroprudential intervention can broadly be classified in four groups (Moreno, 2011). The first group of instruments measures capital inflows. The second group refers to foreign exchange rate intervention and management of foreign reserves. The third group of instruments contains measures to strengthen balance sheets and capital of banks. The last group stresses the management of the quality of credit that banks supply. As and when policy makers apply macroprudential policies it is important that the effect of these instruments must not neutralise other policies.

The problem, however, is that although macroprudential measures in conjunction with other policies mitigate systemic risk, the source of the risk cannot be influenced. Despite implementation of macroprudential policies, the source of the capital surges experienced by BRICS countries is still not neutralised.

\section{Determinants Influencing Exchange Rates}

Kohler (2010) states that exchange rates are predominantly determined by the trading relationship between two countries. Factors that play a role are discussed in the following section.

\subsection{Inflation and interest rate differentials}

Countries with lower inflation rates generally possess currency with higher values and, in turn, much lower interest rates. The purchasing power of the currency, relative to its trading partners, would increase. For developing nations, this would have a profound impact on their balance of payments as the price of their merchandise would increase, causing trading partners to seek cheaper alternatives.

Countries with higher rates of inflation would experience depreciation in the value of their currency, accompanied 
by higher interest rates. These higher interest rates would cause capital inflows as investors seek the highest possible return on their investment. No safeguards exist however, and the only deterrent to this inflow of capital would be a currency appreciation or if the inflation in the country was much higher than in others.

Table 2: Macroprudential instruments

\begin{tabular}{|c|c|}
\hline \multicolumn{2}{|c|}{ 1. Risk measurement methodologies } \\
\hline By banks & Risk measures calibrated through the cycle or to the cyclical trough \\
\hline By supervisors & $\begin{array}{l}\text { Cyclical conditionality in supervisory ratings of firms; Develop measures of systemic vulnerability (e.g. commonality } \\
\text { of exposures and risk profiles, intensity of inter-firm linkages) as basis for calibration of prudential tools; } \\
\text { Communication of official assessments of systemic vulnerability and outcomes of macro stress tests; }\end{array}$ \\
\hline \multicolumn{2}{|c|}{ 2. Financial reporting } \\
\hline \begin{tabular}{|l|l|l} 
Accounting \\
standards
\end{tabular} & Use of less procyclical accounting standards; dynamic provisions \\
\hline Prudential filters & $\begin{array}{l}\text { Adjust accounting figures as a basis for calibration of prudential tools; Prudential provisions as add-on to capital; } \\
\text { smoothing via moving averages of such measures; time-varying target for provisions or for maximum provision rate }\end{array}$ \\
\hline Disclosures & $\begin{array}{l}\text { Disclosures of various types of risk (e.g. credit, liquidity), and of uncertainty about risk estimates and valuations in } \\
\text { financial reports or disclosures }\end{array}$ \\
\hline \multicolumn{2}{|c|}{ 3. Regulatory capital } \\
\hline Pillar 1 & $\begin{array}{l}\text { Systemic capital surcharge; Reduce sensitivity of regulatory capital requirements to current point in the cycle and } \\
\text { with respect to movements in measured risk; Introduce cycle-dependent multiplier to the point-in-time capital figure; } \\
\text { Increased regulatory capital requirements for particular exposure types (higher risk weights than on the basis of } \\
\text { Basel II, for macro prudential reasons) }\end{array}$ \\
\hline Pillar 2 & Link of supervisory review to state of the cycle \\
\hline $\begin{array}{l}\text { 4. Funding } \\
\text { liquidity } \\
\text { standards }\end{array}$ & $\begin{array}{l}\text { Cyclically-dependent funding liquidity requirements; Concentration limits; FX lending restrictions; FX reserve } \\
\text { requirements; currency mismatch limits; open FX position limits }\end{array}$ \\
\hline $\begin{array}{l}\text { 5. Collateral } \\
\text { arrangements }\end{array}$ & $\begin{array}{l}\text { Time-varying Loan-to-value (LTV) ratios; Conservative maximum loan-to-value ratios and valuation methodologies } \\
\text { for collateral; Limit extension of credit based on increases in asset values; Through-the-cycle margining }\end{array}$ \\
\hline $\begin{array}{l}\text { 6. Risk } \\
\text { concentration } \\
\text { limits }\end{array}$ & $\begin{array}{l}\text { Quantitative limits to growth of individual types of exposures; (Time-varying) interest rate surcharges to particular } \\
\text { types of loans }\end{array}$ \\
\hline \begin{tabular}{l|}
$\begin{array}{l}\text { 7.Compensation } \\
\text { schemes }\end{array}$ \\
sches
\end{tabular} & $\begin{array}{l}\text { Guidelines linking performance-related pay to ex ante longer-horizon measures of risk; back-loading of pay-offs; } \\
\text { Use of supervisory review process for enforcement }\end{array}$ \\
\hline \begin{tabular}{|l|} 
8. Profit \\
distribution \\
restrictions
\end{tabular} & Limit dividend payments in good times to help build up capital buffers in bad times \\
\hline $\begin{array}{l}\text { 9. Insurance } \\
\text { mechanisms }\end{array}$ & $\begin{array}{l}\text { Contingent capital infusions; Pre-funded systemic risk insurance schemes financed by levy related to bank asset } \\
\text { growth beyond certain allowance; Pre-funded deposit insurance with premia sensitive to macro (systemic risk) in } \\
\text { addition to micro (institution specific) parameters }\end{array}$ \\
\hline $\begin{array}{l}\text { 10. Managing } \\
\text { failure and } \\
\text { resolution }\end{array}$ & $\begin{array}{l}\text { Exit management policy conditional on systemic strength; Trigger points for supervisory intervention stricter in } \\
\text { booms than in periods of systemic distress }\end{array}$ \\
\hline
\end{tabular}

Source: Galati \& Moessner (2011)

\subsection{Current account deficits}

Any deficit on a country's current account would indicate that the country is spending more on foreign trade than it is earning. The country, essentially, requires more foreign currency than it receives, and supplies more of its own currency than demanded for its products by foreign markets. This outflow of capital causes the domestic currency to depreciate.

\subsection{Public debt}

Nations with large public deficits are less likely to attract foreign investors as debt encourages inflation. Shapiro (2006) indicates that governments may print money in order to pay off the debt, but this action would cause an increase in 
inflationary pressure within the economy. If governments cannot service their debt through domestic instruments then the only recourse available is to increase the sale of securities to foreigners (often lowering their price in order to attract investment). A country's debt rating is often crucial to the determination of its exchange rate as foreign investors would be less likely to own securities if the risk of default is great.

\subsection{Economic growth rates and terms of trade}

Nations with strong economic growth rates would attract investment (Shapiro, 2006). The demand for domestic assets would cause an increase in the demand for domestic currency. Nations with low growth prospectus can expect an exodus of potential capital investment and a weakening of its currency. Favourable terms of trade indicate increased demand for the country's exports.

\subsection{Political stability}

Investors seek stable countries with no inherent political risk. Any instability would result in an immediate outflow of capital and a resultant depreciation of the domestic currency.

\section{Theoretical Views Regarding Exchange Rates}

\subsection{The Keynesian perspective}

The IMF considers an exchange rate regime that has unregulated capital markets (unrestricted capital mobility) and flexible exchange rates as ideal for emerging economies. Ferrari-Filho and de Paula (2009) indicate that such a regime would regard domestic financial assets as substitutes for international securities. Effective monetary policy would be determined by domestic and international interest rates, whereby monetary expansion would decrease interest rates to levels below the international norm. This, in turn, would result in capital flight and domestic exchange rate depreciation, which raises domestic interest rates until equilibrium is established in the balance of payments. Keynesian economists are of the opinion that capital management techniques and an exchange rate regime that prevents excessive exchange rate fluctuations are needed in order to achieve macroeconomic stability.

Keynes (1973) indicates that fluctuations in effective demand and the level of employment occur because investors would rather withdraw their investment in light of uncertainty. Keynes's proposals aimed at creating an international market maker that would maintain full employment level and price stability (Ferrari-Filho \& de Paula, 2009). According to Keynes, the creation of an international liquidity currency was a fundamental condition to ensure the creation of funds necessary for balance of payments adjustment and an elastic supply of money which would expand or contract with demand.

Keynes's proposals relating to the international monetary system aimed at stressing macroeconomic management instead of utilising Adam Smith's "invisible hand", reducing investor uncertainties in order to facilitate investment and create a flexible monetary system that would expand demand and employment globally. Keynes recommended that countries adopt a regime of fixed but adjustable exchange rates and capital controls in order to preserve the flexibility of monetary policy and expand the demand for investment.

\subsection{Mundell-Flemming model}

The Mundell-Fleming model is an extension of the IS-LM model in an open economy. The model is often used to argue that an economy cannot maintain a fixed exchange rate, free capital movement and an independent monetary policy.

Obstfeld (2001) indicates that under a flexible exchange rate, the model predicts that an increase in money supply would shift the LM curve downward. This reduces domestic interest to rates lower than international rates, which depreciates the domestic currency. Domestic goods are cheaper as a result, leading to expanded exports and decreased imports. Increased exports causes the IS curve to shift to the right to the point where domestic interest rates equalise with international rates once again.

Any increase in government expenditure would cause local interest rates to increase above the international rate, causing capital inflows. This leads to an appreciation of the domestic currency relative to foreign currencies, thereby leading to increased imports. The IS returns to its original level as a result.

Under fixed exchange rates, the Mundell-Fleming model proposes that the central bank will adjust the exchange 
rate as a result of excess demand or supply for the currency. The exchange rate will be depreciated or appreciated until it reaches its original level (Obstfeld, 2001). Increased government expenditure will shift the IS curve to the right, increasing the interest rate. The central bank would purchase foreign currencies with local currency in order to maintain the exchange rate or relieve pressure from it. This would shift the LM curve in tandem with the IS curve shift, which would increase the local money supply in the local market. The exchange rate remains the same; however, general income in the economy increases.

\section{Symptoms of Interest Rate Differentials}

\subsection{Symptoms of high interest rate spectrums in emerging countries}

To address the impact of international capital and exchange rate volatility on economic growth in emerging countries, and specifically South Africa, the root causes of the problem of capital surges must be investigated and not the symptomatic mechanisms of the volatile capital movements economic dispensation. However, the structure of higher interest rate spectrums in emerging economies (compared to developed countries) has not been scrutinised to the point of being able to find the real cause.

It is important to analyse the framework of the economic system within which the South African economy is operating. This analysis allows the researchers to gain perspective of alternatives to the existing framework.

In the preceding months of the financial crisis in 2008 the world experienced two financial storms (Wolf, 2009). The first storm was the sustained increase in international commodity prices which caused international inflation to rise. The second storm was a deflationary financial storm where the United States of America experienced a credit crunch in their financial markets with a spill over effect to European financial markets.

According to Wolf (2009), two reasons were the cause of these financial storms. The first reason was a surplus of savings which developed globally. The cause of these savings surpluses can be traced to a few countries that experienced persistent surpluses like Japan, Germany and the oil producing countries of the Middle East. Another cause is the shift of emerging countries from deficits into surpluses on their current accounts. China, as the world's largest exporter, became one of the world's biggest investors.

The second reason was the transformation that occurs in the world economy. The emerging economies are growing faster than the traditional Western countries. China as the biggest of these emerging economies is growing very fast on a sustained basis relative to the growth rates of the traditional Western countries. This faster growth of the emerging economies creates a pattern of global imbalances on balance sheets. Most emerging economies develops strong external positions which is resource driven.

According to Bernanke (2010), accommodative policies in advanced economies caused negative spillover effects in emerging economies. These policies induced capital inflows to emerging economies which caused upward pressure on emerging market economy's currencies and also threatened to create asset price bubbles in these economies. These capital flows to emerging economies was driven by perceptions of higher growth and higher interest rates that prevailed in 2010 relative to advanced economies.

Another factor (Bernanke, 2010) that caused the sustained inflow of capital to emerging economies was the incomplete adjustment of the exchange rates by the authorities of these emerging economies. Investors anticipated high returns arising from continued exchange rate appreciation. The authorities of some emerging economies intervened in the foreign exchange markets to prevent a sustained appreciation of their currencies. The authorities of emerging markets that did not intervene aggressively and allowed market forces to determine new levels experienced reduced competitiveness regarding their exports.

Monetary authorities were forced to intervene in the foreign exchange markets. On the one hand, advanced economies pursued with accommodative monetary policies to foster economic recoveries in their economies - interest rates continued to decline. On the other hand, authorities in emerging economies were forced to increase interest rates to prevent overheated economies or rising inflation in the medium term. This simultaneous decrease of interest rates in advanced economies and increase of interest rates in emerging economies lead to big capital inflows to emerging economies. Depending to what extent these authorities intervened in the foreign exchange market, emerging market currencies appreciated which reduced their net exports and current account surpluses. The emerging market economies were at a disadvantage because these economies received sustained capital inflows which harmed their specific economic status. Most of these economies experienced appreciation of their currencies which was to their detriment. This process of capital inflows in emerging economies all began with interest rates being higher than in advanced economies.

Policymakers in the emerging countries face four different challenges (Caruana, 2011). The first challenge is about 
the intrinsic volatility of international financial flows. Emerging economies received foreign capital even before the crisis reached its peak in the second half of 2008. After the third quarter of 2008 , emerging economies lost billions of dollars but received the bulk of those dollars again in 2009 and 2010. The main reasons for this were the robust growth in the emerging economies relative to developed economies as well as the favourable interest rate differentials. This high volatility creates financial instability in the markets and makes it difficult for policymakers to distinguish between the short term and long term nature of these flows.

The second challenge for policymakers is to avoid accommodative financial conditions in the financial markets. Weak growth prospects and historical low interest rate spectrums in the developed economies led to prolonged periods of ultra-low interest rates. This condition in the developed economies raised the attractiveness of financial assets in emerging economies.

The third challenge is that sustained inflows of capital make it difficult to pursue internal stabilization objectives. These capital inflows contribute towards credit growth in local economies as well as inflationary pressures. Policymakers are tempted to increase interest rates to avoid negative spill overs which will only suck more international capital flows. If this happens then the exchange rates will appreciate even worse for emerging economies.

The fourth challenge is the expectation that developed countries' short term rates will remain low for an extended period of time. This scenario attracts carry trade capital where investors borrow cheap in developed economies and invest at a healthy interest margin in emerging economies. The unwinding of these carry trade transactions causes potential and additional volatility.

As long as these ultra-low interest rate spectrums prevail in developed economies, policy makers in emerging economies will experience extreme difficulty to create sustainable financial stability in their local financial markets. It is also difficult for policy makers to distinguish between longer term investments and short term hot money investments. In the next section inflation - and interest differentials will be analysed since the beginning of 2008. The sustained higher nominal interest returns for foreign investors in emerging economies is discussed.

\subsection{Inflation statistics of USA and Europe versus BRICS countries}

\subsubsection{Inflation and interest rate comparison of developed economies since 2008}

The interest and inflation rates for the USA, Europe (combined average for three countries) and Japan were analysed. This selection represents 5 of the G8 countries or $62.5 \%$ of the developed countries in the world. A similar comparison will follow for all 5 members of the BRICS countries. Similar low inflation rates and, therefore, low nominal interest rates are observed in the developed countries. Similar higher inflation rate levels and therefore higher nominal interest rates are observed for all BRICS member countries.

In the first analysis of the developed economies, three distinct conclusions are derived. Firstly, the inflation rates declined substantially after the outbreak of the financial crisis in 2008. Secondly, interest rates declined substantially because of stimulatory monetary policy. Lastly, interest rates continued to stay at record low levels for a long time indicating that the global recovery is very slow (TradingEconomics, 2013).

\subsubsection{Inflation and interest rate comparison of BRICS economies since 2008}

In the second analysis of the BRICS economies, seven distinct conclusions are derived. Firstly, the inflation rates declined substantially after the outbreak of the financial crisis in 2008. Secondly, interest rates declined substantially because of stimulatory monetary policy. Thirdly, when the collapse occurred in the second half of 2008, these countries' exchange rates depreciated because of an outflow of capital. Fourthly, these economies experienced a massive appreciation in 2009 because of capital surges. Fifthly, the inflation rates of these economies continue to be at higher levels than the developed economies which caused higher nominal interest rates to prevail. Sixthly, some of these emerging economies experienced higher interest rates as part of policies to adjust to capital surges and higher growth and inflation pressures relative to developed economies. Lastly, these economies experienced a turnaround of capital surges late in 2011 because of problems in Europe which caused their exchange rates to depreciate again. These effects were muted in China because of their managed exchange rate system.

Interest rates continued to stay at record low levels in developed economies because of very loose monetary policies. Interest rates in all the BRICS economies were higher on a sustained basis than in the developed economies and some of the BRICS monetary authorities increased interest rates as part of their policy kid to manage capital surges and to address rising inflation pressures. As long as these positive interest rate differentials exist between developed 
economies and BRICS economies it will be attractive for foreign investors to invest in these BRICS economies. The root cause of these investments is exogenous and very difficult for the BRICS authorities to manage (TradingEconomics, 2013).

\section{South Africa's Inflation Rate}

\subsection{Analysis of the South African scenario}

The researchers analysed the South African inflation scenario and found numerous aspects which must be addressed to reduce inflation and thus also the nominal interest rate spectrum. Firstly, SARB inflation research will be referred to. The persistence of inflation is determined by how effective monetary policy and fiscal policy address inflationary pressure in the economy. Policy measures must also address second round price effects before these effects increase inflation (Anon, 2010). These statements are questionable. Reasons being that SARB acknowledge that inflation is persistent in the South African economy and that none other policy measures are referred to than only monetary policy and fiscal policy. Furthermore, that SARB must address second round effects before these effects take place. These second round effects are normally associated with a cost push inflation scenario, because according to theory an adjustment in the repo rate will not affect first round effects of cost push inflation. Therefore, the measurement of these second round effects and the timing of monetary policy measures are questionable.

Secondly, administered prices will be addressed. Administered prices are defined as prices that are determined by government or through a government agency without any reference to market forces (Anon, 2010). Administered goods and services comprise 17.89\% of the 2008 headline CPI basket according to (Anon, 2010). The following administered prices are included in the new CPI basket which is calculated since January 2008:

- Housing (sanitary fees, refuse removal, assessment rates, water and university boarding fees);

- Fuel and power (electricity and paraffin);

- Medical care (public hospitals);

- Communication (telephone calls, telephone rental and installation, postage, cellphone connection fees and calls);

- Education (school fees and university, technicon and college fees);

- Transport (petrol, public transport - municipal buses and trains, motor licenses and registration), and

- Recreation and entertainment (television license).

By comparing Tables 4 and 5 , it is clear that administered prices since 2010 influenced the CPI negatively. The only exception was in 2009, which was caused by an appreciation of the rand currency. The CPI for the different years since the implementation of the new index and base year was as follows: $7.1 \%$ for $2009,4.3 \%$ for $2010,5.0 \%$ for 2011 and $5.6 \%$ for 2012 (StatsSA, 2013). A disturbing fact is that the negative influence of administered prices is escalating.

The monetary authority addresses increases in administered prices by voicing their opinion on increases. According to Anon (2010) the "monetary authorities may endeavour to achieve a "buy-in" from other entities in the economy to try and avert unwarranted administered price increases. The only "instrument" immediately at the disposal of the monetary policy authority in dealing with administered price adjustments is moral persuasion. The effectiveness of such intervention is subject to the political will of all concerned". This policy strategy is clearly not a recommended method to get the political will changed of other government departments. The problem here may be not only a lack of political will, but also a lack of economic literacy. 
Table 3: CPI excluding administered prices

\begin{tabular}{|c|c|c|c|c|c|c|c|c|c|c|c|c|c|c|}
\hline & Jan & Feb & Mar & Apr & May & Jun & Jul & Aug & Sep & Oct & Nov & Dec & Ave- rage [1] \\
\hline Year & Index/rate & \multirow{2}{*}{77.50} & \multirow{2}{*}{77.90} & \multirow{2}{*}{78.90} & \multirow{2}{*}{79.20} & \multirow{2}{*}{79.60} & \multirow{2}{*}{80.60} & \multirow{2}{*}{81.10} & \multirow{2}{*}{81.70} & \multirow{2}{*}{82.50} & \multirow{2}{*}{82.90} & \multirow{2}{*}{83.10} & \multirow{2}{*}{83.60} & \multirow{2}{*}{80.70} \\
\hline \multirow{2}{*}{2008} & Index & & & & & & & & & & & & & \\
\hline & Rate & & & & & & & & & & . & & & . \\
\hline \multirow{2}{*}{2009} & Index & 84.50 & 85.40 & 86.40 & 86.70 & 87.00 & 87.30 & 87.60 & 87.80 & 88.10 & 88.20 & 88.20 & 88.40 & 87.10 \\
\hline & Rate & 9.00 & 9.60 & 9.50 & 9.50 & 9.30 & 8.30 & 8.00 & 7.50 & 6.80 & 6.40 & 6.10 & 5.70 & 7.90 \\
\hline \multirow{2}{*}{2010} & Index & 88.70 & 89.30 & 89.90 & 89.90 & 90.00 & 90.20 & 90.10 & 90.20 & 90.30 & 90.60 & 90.60 & 90.70 & 90.00 \\
\hline & Rate & 5.00 & 4.60 & 4.10 & 3.70 & 3.40 & 3.30 & 2.90 & 2.70 & 2.50 & 2.70 & 2.70 & 2.60 & 3.30 \\
\hline \multirow{2}{*}{2011} & Index & 91.10 & 91.70 & 92.60 & 92.70 & 93.10 & 93.50 & 93.90 & 93.90 & 94.40 & 94.80 & 95.00 & 95.20 & 93.50 \\
\hline & Rate & 2.70 & 2.70 & 3.00 & 3.10 & 3.40 & 3.70 & 4.20 & 4.10 & 4.50 & 4.60 & 4.90 & 5.00 & 3.90 \\
\hline \multirow{2}{*}{2012} & Index & 95.90 & 96.40 & 97.20 & 97.30 & 97.30 & 97.90 & 98.00 & 98.10 & 98.70 & 99.40 & 99.70 & 100.00 & 98.00 \\
\hline & Rate & 5.30 & 5.10 & 5.00 & 5.00 & 4.50 & 4.70 & 4.40 & 4.50 & 4.60 & 4.90 & 4.90 & \begin{tabular}{|l}
5.00 \\
\end{tabular} & 4.80 \\
\hline \multirow{2}{*}{2013} & Index & 100.40 & 101.50 & 102.10 & 102.40 & 102.50 & 102.90 & 103.10 & 103.30 & 103.90 & 104.30 & 104.50 & 104.8 & 103.0 \\
\hline & Rate & \begin{tabular}{|l}
4.70 \\
\end{tabular} & 5.30 & 5.00 & 5.20 & 5.30 & \begin{tabular}{|l}
5.10 \\
\end{tabular} & 5.20 & 5.30 & 5.30 & 4.90 & 4.80 & 4.8 & 5.1 \\
\hline
\end{tabular}

Source: StatsSA (2013)

Table 4: CPI for regulated administered prices

\begin{tabular}{|c|c|c|c|c|c|c|c|c|c|c|c|c|c|c|}
\hline & & Jan & Feb & Mar & Apr & May & Jun & Jul & Aug & Sep & Oct & Nov & Dec & Ave- rage [1] \\
\hline Year & \begin{tabular}{|c} 
Index/rate \\
Index
\end{tabular} & 62.80 & 63.30 & 65.30 & 67.50 & 69.20 & 70.90 & 76.30 & 76.20 & 74.00 & 73.30 & 71.80 & 66.80 & 69.80 \\
\hline 2008 & Rate & & & & & & & & & & & & & \\
\hline \multirow{2}{*}{2009} & Index & 62.40 & 64.30 & 65.70 & 66.80 & 66.70 & 67.10 & 72.50 & 72.80 & 73.80 & 72.60 & 72.60 & 73.50 & 69.20 \\
\hline & Rate & -0.60 & 1.60 & 0.60 & -1.00 & -3.60 & -5.40 & -5.00 & -4.50 & -0.30 & -1.00 & 1.10 & 10.00 & -0.90 \\
\hline \multirow{2}{*}{2010} & Index & 73.20 & 73.80 & 73.80 & 75.40 & 75.90 & 74.90 & 78.60 & 78.70 & 78.40 & 78.60 & 79.20 & 79.60 & 6.70 \\
\hline & Rate & 17.30 & 14.80 & 12.30 & 12.90 & 13.80 & 11.60 & 8.40 & 8.10 & 6.20 & 8.30 & 9.10 & 8.30 & 10.80 \\
\hline \multirow{2}{*}{2011} & Index & 80.60 & 81.40 & 82.80 & 84.60 & 85.50 & 85.50 & 89.20 & 89.70 & 90.00 & 91.30 & 92.00 & 91.70 & 87.00 \\
\hline & Rate & 10.10 & 10.30 & 12.20 & 12.20 & 12.60 & 14.20 & 13.50 & 14.00 & 14.80 & 16.20 & 16.20 & 15.20 & 13.40 \\
\hline \multirow{2}{*}{2012} & Index & 91.50 & 92.50 & 93.50 & 95.80 & 96.70 & 95.00 & 95.70 & 96.80 & 99.70 & 100.50 & 100.30 & 100.00 & 96.50 \\
\hline & Rate & 13.50 & 13.60 & 12.90 & 13.20 & 13.10 & 11.10 & 7.30 & 7.90 & 10.80 & \begin{tabular}{|l}
10.10 \\
\end{tabular} & 9.00 & \begin{tabular}{|l|}
9.10 \\
\end{tabular} & 10.90 \\
\hline \multirow{2}{*}{2013} & Index & 99.50 & 101.00 & 104.00 & 104.40 & 101.80 & 101.70 & 107.90 & 109.20 & 108.90 & 108.40 & 107.20 & & \\
\hline & Rate & 8.70 & 9.20 & 11.20 & 9.00 & 5.30 & 7.10 & 12.70 & 12.80 & 9.20 & 7.90 & 6.90 & & \\
\hline
\end{tabular}

Source: StatsSA (2013)

An economist of Investec Bank in South Africa, Annabel Bishop, stated that lower inflation is possible if increases in administered prices can be mitigated (Van Zyl, 2012). According to Bishop, several reasons cause high administered prices that prevail in South Africa. Examples are squandering, inefficiency and corruption of government and semi government institutions and the fact that South African consumers are penalized with high tariffs to pay for capital expenditure of semi government institutions like Eskom. In addition to the high tariffs, consumers carry the burden of the government through subsidization of free electricity for the low income groups in South Africa. The use of government property for personal use by government officials is another example of inefficiency. Lastly, proper management of costs will filter through to consumers by means of lower prices for government services which are not the case. According to this analysis, various examples exist for government to reduce administered prices. But the question is if the political will and economic literacy of government officials exist to implement these changes.

Thirdly, the methodology and bias of the current CPI basket must be addressed. According to Anon (2010) if "an index is not regularly rebased when a fixed-weight methodology is used, a substitution bias will emerge where high inflation items have a higher effective weight over time, which places an upward bias on inflation. This means that simply rebasing the $\mathrm{CPI}$ series (without changing the weights or basket of goods) should have a downward impact on overall inflation. Based on May 2008 inflation numbers, it is estimated that the rebasing of the index alone can reduce total inflation by about 1.2 percentage points. Estimates show that the reweighting exercise has reduced overall inflation further by about 2.0 percentage points at current levels of food and petrol price inflation, at the time of analysis in May 
2008". According to this research done by the South African Reserve Bank the interval of years between rebasing and reweighting must be reduced without a shadow of a doubt.

Fourthly, research done in respect of the repo rate elasticity will be referred to. The Bureau of Market Research of the University of South Africa has done research about the impact of interest rates on inflation and unemployment. Two types of analysis were done to determine which prices in the CPI basket are sensitive to changes in the repo rate. The elasticity research revealed that $53 \%$ of the prices of products in the CPI basket are insensitive to and changes in the repo rate (Van Aardt et al., 2011). This denominator increases to $73 \%$ if the prices of products with small elasticity are added if the repo rate changes.

This research has shown that a number of interest rate changes must be initiated by SARB to have any meaningful impact on prices and therefore inflation. The results further proved that prices of products in the CPI basket are more likely influenced by other factors such as a change in the exchange rate, price changes of international commodities, administered price changes and competitive pricing practices. According to Van Aardt et al, (2011) the results clearly shows "that traditional macro-economic policy whereby the Minister of Finance sets the inflation target and then leaves it to the Reserve Bank to achieve the target via the use of interest rates, are not yielding results a country such as South Africa - with a very high unemployment rate and high rates of interest rate inelastic prices - deserves. The Reserve Bank cannot be held solely responsible for achieving the inflation target. Government must also play its part by keeping administered price increases as low as possible via efficiency gains, whilst structural inflation must be eliminated via among others fierce competition policy. South Africa has a large component of structural inflation that cannot be eliminated via higher interest rates".

Fifthly, Glenn Rudebusch, senior vice-president of the Federal Reserve Bank of San Francisco, developed another method to determine the optimal level of interest rates (Rudebusch et al., 1998). These researchers used the Taylor rule to evaluate the weights that monetary policy apply to address inflation and unemployment. Two gaps are analysed, namely how the monetary policy authorities should change the real interest rate if inflation misses its target and if GDP misses potential GDP (Van N Fourie et al., 2009).

The research done in the USA was for three different periods when the Federal Reserve Bank had three different chairmen. This rule recommends a high real rate when the inflation is above its inflation target and if the economy is at potential or full capacity. If the inflation rate is within the target range and the economy experiences high unemployment, then the real interest rate level must decrease substantially.

The Bureau of Market Research at UNISA applied this equation for the South African circumstances (Van Aardt et al., 2011). In this South African scenario the researchers addressed inflation and unemployment as two equal goals of monetary policy. Unemployment was not addressed as a subordinate target relative to inflation as is the case in the South African monetary policy. The expanded unemployment rate was used because the researchers felt that the expanded unemployment rate is a true reflection of unemployment in South Africa and no specific target range was used for inflation. The results for 2011 was startling, namely that the prime rate should have been $5.2 \%$ rather than the $9 \%$ that prevailed. This research proved that the interest level in South Africa is too high if specific circumstances are addressed, namely exceptional high unemployment.

Lastly, various structural problems exist in the South African economy that causes inflation to be higher than it should be if a developed scenario prevailed. Almost all of these factors are labour related, namely low productivity, inadequate skills levels, and high cost of labour relative to the competitors of South Africa and labour unions that is politicised. The labour laws that are inflexible can also be added. These labour related factors cause higher production costs which also reduce the South African competitiveness of exports. Various reports emphasize these facts, for example the selected country report done by the IMF (Coorey et al., 2008). According to this country report the real growth rate can be three percent higher if the productivity growth was the same as countries in the panel research done by the IMF and nearer to its potential.

\subsection{Applying old theories in a new way: the case of South Africa}

The chief economist of the IMF, Oliver Blanchard, admitted during 2011 that macroeconomic policies are inadequate after the 2008 financial crisis to deal with the economic problems of the world. Blanchard (2011) states that monetary policy is not only about inflation stability anymore and output and financial stability must be added. Many policy instruments are available, for example macro prudential measures in addition to monetary and fiscal policy measures. The question however is the uncertainty of policy makers to use these instruments in the correct mix. The crisis questioned the beliefs of authorities to conduct the different policies. Blanchard elaborated that new distortions in macroeconomics developed, more distortions than authorities believed before the crisis existed. Behavioural economics and behavioural finance are 
perfect examples of new fields of research which must be added to the scope of authorities to address instability in the financial markets.

According to Blanchard (2010) it is easy to identify the flaws of existing policy. The financial crisis taught policy makers that macroeconomic policy must address numerous targets. The problem however is to identify the correct mix of policy instruments and regulatory instruments towards multiple targets. Many questions about future policy application require substantial research to address the probable solutions to improve financial stability in the markets. Examples of probable questions are: should the inflation targets of countries be raised; how should monetary and regulatory policy be combined; how should inflation targeting and foreign exchange intervention be combined; how should liquidity be provided by the central bank; should fiscal space be created during good times and which automatic fiscal stabilizers are required?

One of the outcomes of the financial crisis is that very big capital flows were triggered towards emerging economies. These capital flows may be beneficial at times for some receiving countries, but surges in capital inflows to emerging economies carries different risks for such economies and the management of this increased liquidity in the financial systems (Strauss-Kahn, 2011). Such capital surges pose various challenges for the policy makers such as how to cope with the currency appreciation and such surges may also create asset price bubbles and increased credit growth. The sudden reversal of these inflows also causes big challenges for policy makers. South Africa and all the BRICS countries (except China because of their managed exchange rate dispensation) experienced such outflows during the second half of 2011 which caused the exchange rates to depreciate again.

The questions to address these capital surges are numerous. More examples of probable questions are: how should policy makers employ capital control measures; when and how much reserves should be accumulated; should countries employ their own measures and should there be international rules that emerging countries must abide to? The managing director of the IMF stated what is probable (Strauss-Kahn, 2011). The authorities of different countries should apply the following principles when employing policies. Firstly, no policy measure fits all countries because of the specific state of each economy. Secondly, structural reforms to increase the capacity of domestic capital markets should be encouraged. Thirdly, correct macro policies should be pursued all the time. Fourthly, capital controls should be part of each policy toolkit. Fifthly, policies should be applied to address the specific financial instability concerns and must be withdrawn again when the instability recedes. Lastly, policies applied in specific countries must not discriminate against other countries. These principles may be true, but it is vague and general. It does not give a BRICS country policy authority the specific tools to address capital surge inflows or outflows.

Policymakers face numerous questions and uncertainties about policy application to address capital surges as well as the sudden reversal of these inflows. If policy makers address capital surges the root causes of the capital volatility between developed and emerging countries are not addressed. As policymakers apply instruments and combination of instruments, the symptoms of capital surges and reversals are addressed. The root cause of the problem of capital surges is not addressed in the research of various international institutions namely the structure and level of higher interest rate spectrums in the different emerging economies.

The interest rate spectrum in all the BRICS countries are higher than in the developed economies (refer to section 6.2). All the BRICS countries experienced capital surges because of their higher interest rate spectrum. If the interest levels of these economies were much lower or the same than the interest rate levels in the developed economies the magnitude of the capital surges would be negligible. The negative impact on the local economies for example exchange rate volatility and the policy challenges to address such volatility would also be much less.

The researchers analysed the core reason why interest rate differentials exist in South Africa relative to developed economies, namely a higher inflation rate. The solution to reduce the negative impact of capital surges lies with inflation management in each BRICS country. This research focused on the South African inflation scenario. Numerous reasons for the higher inflation in South Africa were analysed in section 7.1. A similar study can be conducted for each of the other BRICS countries.

The traditional method to address a rising inflation rate is contractionary monetary policy. The traditional tactic is to increase interest rates to address the first round effect of demand-pull inflation or the second round effect of cost-push inflation. As interest rates increase the demand is curbed and the rising trend of inflation comes to an end. But if the South African monetary policy makers increase the repo rate, the interest rate differential relative to developed countries will increase. The researchers indicated in section 7.1 that the cause of inflation after the 2008 financial crisis is not demand-pull inflation. The cause is rather structural and of a cost-push nature. Empirical tests proved to distinguish between the first and second round effects of any supply shock is difficult which hampers the response of policy makers (Cuevas et al, 2008).

The underlying factors and propagating factors which cause a higher inflation in South Africa must be addressed 
(Van N Fourie et al, 2009). To address the higher inflation in South Africa relative to developed economies, a structuralist approach is necessary. A coordinated strategy of monetary policy authority, labour, other semi government institutions and other policy makers is necessary to reduce the inflation level. The likelihood that such a structuralist approach will occur in South Africa is slim. The scope for the monetary authority to address a declining income and gross domestic product because of supply shocks is also limited. The theory of the augmented Phillips curve verifies that a sustained output is achieved at a higher inflation rate (Van N Fourie et al, 2009). A new tactic is needed to reduce inflation and thus interest rates.

A new inflation index is proposed to reduce the negative impact of capital surges in the South African economy. The monetary policy makers use a new CPI index since January 2008. Various problems with this index were highlighted in section 7.1, for example the negative impact of administered prices, the $53 \%$ inelastic nature of the prices in the basket and several other structural problems of the South African dispensation. A new CPIX index is proposed which will exclude all exogenous factors which the monetary authorities cannot manage with traditional interest rate management.

The Bank of Canada adopted a new measure of core inflation when the inflation targets were renewed in 2001 (Macklem, 2001). The new CPI measure excludes the eight most volatile components from the basket and also adjusts the remaining components for the effect of changes in indirect taxes. This new measure of inflation measurement has a firmer statistical basis, an improved correspondence with economic theory and also predicts future inflation better than the previous index. This kind of new index is needed in South Africa which will exclude the administered prices and structural problems which traditional monetary policy cannot address. A monetary policy stance with a new index is necessary to reduce the interest rate spectrum in South Africa.

\section{Conclusion}

The financial crisis of 2008 influenced the international economic environment in many ways. A few examples are capital volatility, exchange rate volatility, destabilized imbalances all over the world, high unemployment and rethinking of policies. Since the crisis monetary policy makers look broader than inflation stability and address financial stability as well. Monetary policy makers therefore have to address numerous targets and have to apply a new mix of policies. No old and existing policy measures is good enough anymore and the outcome of new combinations of policies or new measures are in uncertain territory.

Various negative consequences developed for example BRICS countries that experienced capital surges because of very loose monetary policy in developed economies. Other problems are high debt of governments and big budget deficits which hamper a continuous counter cyclical fiscal policy application. Very high unemployment in the world and policy challenges to reduce unemployment to normal levels again will also be part of international agendas for a long time. These latter consequences where not part of this research. Any new policies or new policy mix of policymakers were also not part of this research.

The rethinking of inflation theory to address the capital surges which emerging economies face is of utmost importance. The solution to reduce the negative impact of capital surges lies with inflation management in each BRICS country. This research focused on the South African inflation scenario. The reasons why international investors invest in South Africa and other BRICS countries are of an exogenous nature. Existing policies can only influence the outcome, but cannot address the source of the investment.

A new inflation index is proposed for South Africa to reduce the negative impact of capital surges in the South African economy. The high interest rate spectrum and the core reason for attracting foreign capital are addressed. The root causes of the capital surges were investigated and not the symptomatic mechanisms to reduce the impact. The new index which excludes all exogenous factors will allow National Treasury to introduce a much lower inflation target for the monetary authority to manage. The interest rate differential of South Africa will narrow significantly relative to developed economies. If the government can buy in towards a coordinated structuralist approach, the outcome will improve so much more. Other countries have a broader policy application, namely where industrial, labour and competition policies are coordinated towards the combat of inflation.

This reduced interest spectrum will also bring other advantages. The difficulty to introduce new policy instruments and new policy mixes to address imbalances will reduce. A lower interest rate spectrum will also cause significant other macroeconomic benefits. A lower interest rate will stimulate real growth, increase employment opportunities and contribute towards a reduction in poverty. Similar research can be done for the other BRICS countries. If the interest rate spectrum can be reduced in these emerging economies, the world will be a better place to live in. The positive outcomes will be higher growth in the world, reduced unemployment and also a reduction in challenges and cost to reduce poverty. 


\section{References}

Anon. (2010). Monetary policy and the measurement of inflation: prices, wages and expectations - a South African perspective. BIS papers 49, 331 - 345. Pretoria: South African Reserve Bank.

Bernanke, B. S. (2010). Rebalancing the Global Recovery. Sixth ECB Central Banking Conference, 18 - 19 November 2010. Frankfurt: Germany.

Blanchard, O., Dell'Ariccia, G., \& Mauro, P. (2010). Rethinking Macroeconomic Policy. IMF Staff Position Note, 12 February 2010. IMF, Washington, D.C.

Blanchard, O. (2011). The Future of Macroeconomic Policy: Nine tentative conclusions. Posted 13 March 2011 by IMFdirect. [Online] Available:http://www.imf.org/blanchard (Dec 15, 2013)

Caruana, J. (2011). Capital flows to the emerging market economies: a perspective on policy challenges. Speech by the General Manager of BIS, at the Forty-sixth SEACEN Governors' Conference, Colombo, Sri Lanka, 24 - 26 February, 2011.

Coorey, S., Cuevas, A., Gueorguiev, N., \& Eyraud, I. (2008). South Africa: Selected Issues. IMF Country Report 8/347, August 2008. IMF, Washington, D.C.

Cuevas, A., \& Topak, S. (2008). Monetary policy and Relative Price Shocks in South Africa and other Inflation Targeters. IMF Working Paper, 289 of 2008. IMF, Washington, D.C.

Ferrari-Filho, F., \& de Paula, L. F. (2009). Exchange rate regime proposal for emerging countries: a Keynesian perspective. Journal of post Keynesian economics. Vol. 31(2), Winter, 227-248.

Galati, G., \& Moessner, R. (2011). Macroprudential policy - a literature review. BIS Working Papers, no 337. February, 2011. Basel, Switzerland.

Ghosh, A. R., Chamon, M., Crowe, C., Kim, J. I., \& Ostry, J. D. (2009). Coping with the Crisis: Policy Options for Emerging Market Countries. International Monetary Fund Research Paper, 23 April 2009. Washington, USA.

Hoogduin, L. (2010). Macroprudential instruments and frameworks: a stocktaking of issues and experiences. BIS report submitted by the Committee on the Global Financial System, no 38. May 2010. Basel, Switzerland.

Keynes, J. M. (1973). The General Theory of Employment, Interest and Money. Cambridge: University Press.

Kohler, M. (2010). Exchange rates during financial crises. BIS Quarterly Review, March. Basel, Switzerland.

Macklem, T. (2001). A New Measure of Core Inflation. Bank of Canada Review, Autumn 2001.

Mishkin, F. S. (2010). Monetary Policy Strategy: Lessons from the Crisis. Sixth ECB Central Banking Conference, 18 - 19 November 2010. Frankfurt: Germany.

Moreno, R. (2011). Policymaking from a macro prudential perspective in emerging market economies. BIS Working Papers. No. 336. January 2011.

Obstfeld, M. (2001). International macroeconomics: beyond the Mundell-Fleming model. IMF Staff Papers, Vol 47. IMF, Washington, D.C.

Santomero, M. (2001). What monetary policy can do and cannot do. Speech presented to National Association of Business Economics, New York, September 10, 2001.

Shapiro, A. C. (2006). Multinational financial management. (8th ed.). New Jersey:Wiley.

StatsSA (Statistics South Africa). (2013). Consumer Price Index. Pretoria: Government Printer.

Stern, G., \& Miller, P. (2004). Avoiding Significant Monetary Policy Mistakes. Federal Reserve Bank of Minneapolis Quarterly Review, Vol. 28 (2), December 2004, 2 - 9.

Strauss-Kahn, D. (2011). IMF Develops Framework to Manage Capital Inflows. IMF Survey online April 5, 2011. [Online] Available:http://www.imf.org/survey (Dec 15, 20132)

Strauss-Kahn, D. (2011). New Emphasis on IMF's Global Monitoring Role. International Monetary and Financial Committee of IMF and World Bank spring meeting, Washington D.C., 17 April 2011.

Wolf, M. (2009). Global monetary and financial disorder: the role of global imbalances. BIS papers, no 45, Whither monetary policy? Seventh BIS Annual Conference, 26 - 27 June, 2008. Basel, Switzerland.

Van Aardt, C., \& Van Tonder, J. (2011). Optimal Prime Rate Estimates using the Rudebusch Method. Research Study commissioned by the Union UASA. Research conducted by Bureau of Market Research. Pretoria: UNISA.

Van N Fourie, F., \& Burger, P. (2009). How to think and reason in Macroeconomics. Claremont: Juta.

Van Zyl, A. (2012). Staat moet pryse beheer. Sake24, 6 Januarie, 2012, (1).

Zhu, M. (2011). Managing Capital Flows in Emerging Markets. Research paper of special advisor to the Managing Director of IMF. 26 May, 2011. Rio de Janeiro, Brazil. 